\title{
Permukiman Tumbuh Dengan Prinsip Metabolisme di Atas LAHAN BENCANA LUMPUR LAPINDO SIDOARJO
}

\author{
Gyrass Reza Ksatria, Kusumaningdyah N.H, Titis Srimuda Pitana \\ Program Studi Arsitektur \\ Universitas Sebelas Maret Surakarta \\ Email : gyrassic@gmail.com
}

\begin{abstract}
An explosion of hot mudflow occurred on May 29, 2006 in the mining area of Lapindo. Initially, the continuous mudflow only flooded the mining area of Lapindo but now it also flooded residential areas. Some families are now forced to live in the house paved with mud because of their inabilities to move and start a new life elsewhere. Many efforts have been done by the residents to continue their life still in the area affected by the mud. The study is to answer the challenges that human is able to live and work in conditions side by side with extreme environments, returned to live in places that have now been affected by the mudflow, the design of settlements to grow that is capable to accommodate the activities of living on land these Lapindo mud disaster. The method used is the principle of architecturial metabolisme. By using the principle of this metabolisme there are two important parts used they are: massive structure and adaptive system of metabolisme. The result of the study is a growing residential design that can provides life activities on the land of Lapindo mudflow disaster.
\end{abstract}

Keywords: growing civilization, lapindo mudflow, Metabolisme Architecture

\section{PENDAHULUAN}

Ledakan semburan lumpur panas yang terjadi di area pertambangan Lapindo tidak hanya memberikan dampak secara fisik kepada alam, namun juga telah melumpuhkan gerak kehidupan yang pernah ada di sana sebelum tragedi ini. Dampak ini tidak hanya dirasakan di dalam wilayah tanggul, namun juga wilayah sekitar yang sedikit banyak terkena dampak. Tak hanya menggenangi area pertambangan Lapindo kini menyeruak membanjiri kawasan permukiman, pertanian, dan perindustrian di tiga kecamatan di sekitarnya, berpusat di lokasi pengeboran Lapindo Brantas Inc di Dusun Balongnongo, Desa Renokenongo, Kecamatan Porong, Kabupaten Sidoarjo, Jawa Timur.

Kejadian ini merupakan bencana akibat manusia dalam skala yang sangat masif dan mempengaruhi kegiatan perekonomian di Jawa Timur. Selain permukiman, ada pula sawah sawah yang dahulu produktif kini sudah tidak terlihat lagi jejaknya.

Seiring dengan perkembangan keterampilan dan kemampuan manusia untuk beradaptasi maka sedikit demi sedikit kebutuhan yang tidak terdapat dalam suatu lingkungan bisa diciptakan sehingga manusia pada akhirnya mampu bertahan dan menetap dalam suatu wilayah.

Waktu pun memberi manusia kesempatan untuk mengembangkan kemampuannya tidak hanya beradaptasi tetapi juga untuk mengembangkan teknologi dalam membantu mereka mengatasi masalah-masalah yang ditemui.

Namun segala bentuk gerak kehidupan manusia kini masih berada dalam zona aman alam, manusia masih memiliki ruang untuk membangun di atas lahan yang ideal untuk hidup dan tumbuh. Bagaimana ketika zona aman ini sudah tidak memadai?

Studi ini adalah untuk mempersiapkan sebuah bentuk evolusi bermukim yang baru, sebuah upaya menciptakan ruang untuk manusia agar mampu hidup dan tumbuh tidak hanya pada zona aman alam, namun juga pada wilayah-wilayah ekstrim seperti pada wilayah bencana. Penulis mencoba mengangkat isu luapan lumpur yang terjadi di Porong, Sidoarjo, sebagai contoh kasus untuk dipelajari bagaimana jika di atas lahan terdampak bencana diciptakan ruang untuk manusia tinggal dan hidup. 


\section{METODE}

Metode desain yang penulis lakukan untuk menciptakan Permukiman Tumbuh di atas Lahan Lapindo dibagi menjadi dua tahapan, yaitu penentuan bentuk infrastruktur yang merupakan jalur sirkulasi yang akan berjejaring dan konsep bentuk serta pengolahan bangunan dan permukiman.

1. Penciptaan Infrastruktur

Sirkulasi merupakan bagian penting dalam jejaring permukiman yang direncanakan, jejaring permukiman didesain dengan menggabungkan teori dari beberapa sumber untuk menciptakan sebuah hunian yang memiliki sistem mandiri seperti prinsip metabolisme namun dapat beradaptasi dengan mudah ketika akan dilakukan tahapan pengembangan selanjutnya.

2. Rencana Pembangunan

Analogi pembangunan diadaptasi dari sistem tumbuh makhluk hidup, mendekati prinsip metabolisme yang digunakan. Permukiman direncanakan memiliki base yang secara fleksibel dapat menghadapi kemungkinan perkembangan, dasar ide ini kemudian menjadi struktur masif yang akan menjadi tempat permukiman akan didirikan.

Permukiman merupakan unit-unit mandiri yang bisa dengan leluasa tumbuh dan dikembangkan sesuai kebutuhan lingkungannya.

\section{ANALISIS}

\subsection{Analisis Peruangan}

Kebutuhan fisiologis adalah paling awal yang harus dipenuhi atau kebutuhan utama yang berkaitan dengan jasmani manusia.

Tabel 1.Kebutuhan Ruang

\begin{tabular}{|l|l|}
\hline KEBUTUHAN & \multicolumn{1}{|c|}{ PERUANGAN } \\
\hline Istirahat & Kamar tidur \\
\hline Makan & Dapur \\
\hline Ekskresi & Kamar mandi \\
\hline Servis & Tempat penyimpanan \\
\hline Lainnya & $\begin{array}{l}\text { Ruang keluarga, ruang } \\
\text { tamu }\end{array}$ \\
\hline
\end{tabular}

Pada Tabel 1. terlihat kebutuhan peruangan yang dibutuhkan berdasarkan kegiatan.

\subsection{Analisis Lokasi}

Analisis pemilihan lokasi didasarkan pada kondisi wilayah terdampak saat ini, dengan memperhitungkan kemungkinan kondisi di masa yang akan datang. Beberapa aspek menjadi penilaian penting, yaitu:

1. Kondisi lumpur

Tanggul lumpur saat ini telah mencapai tinggi 12-15 meter dengan luas area sekitar 650 hektar, beberapa titik masih aktif teraliri lumpur dan beberapa wilayah telah menjadi dataran lumpur kering, seperti dapat kita lihat pada Gambar 1. Pada perencanaan awal, permukiman akan dibangun dalam wilayah aman di atas lumpur kering.

Pemetaan pada Gambar 2, wilayah yang diwakili dengan warna merah merupakan wilayah dengan kerawanan tinggi karena sifat lumpur yang ada di sana merupakan lumpur basah, area merah di tengah merupakan pusat semburan. Pada perencanaan awal, permukiman akan dibangun dalam wilayah aman di atas lumpur kering.

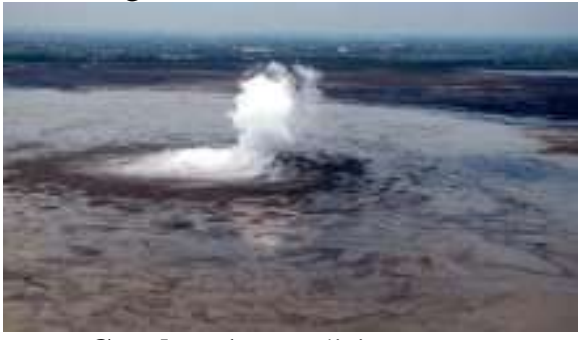

Gambar 1. Kondisi Lumpur (sumber: Syafi, tempo.co)

2. Jarak dengan pusat semburan

Semburan lumpur tidak hanya mengeluarkan lumpur panas, melainkan juga gas panas yang cukup berbahaya jika manusia terus-menerus menghirupnya. Wilayah dengan jarak lebih dari $1 \mathrm{~km}$ merupakan yang paling aman karena dampak gas sudah tidak terasa lagi pada jarak ini, ditambah dengan kuantitas dan frekuensi semburan yang sudah tidak sebesar dahulu. 


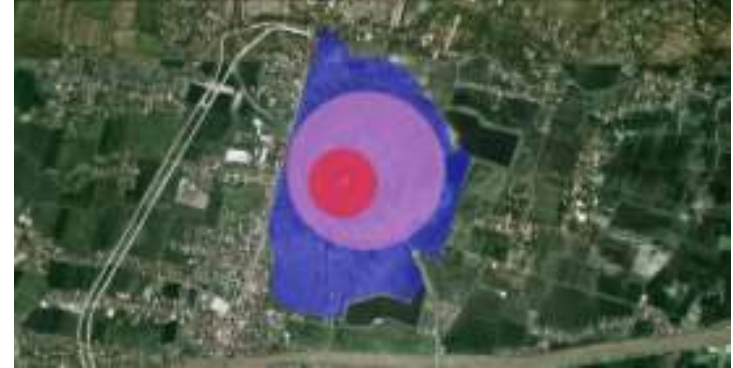

Gambar 2. Pemetaan Wilayah Berdasarkan Jarak terhadap Pusat Semburan

(sumber: images.google.com)

Lingkaran merah : menandakan wilayah berbahaya rawan paparan gas dengan jarak sekitar 500 meter sekitar pusat semburan.

Lingkaran merah muda : wilayah penyesuaian ini merupakan jarak aman untuk pengamatan dan penelitian pusat semburan, tidak diperuntukkan untuk terlalu lama di wilayah ini karena masih ada sedikit gas yang terpapar.

Lingkaran Ungu : Area aman bagi para pekerja untuk mengelola lumpur dan wilayah dibangunnya dan letak alat berat pekerja.

\subsection{Analisis Meso}

Analisis meso merupakan analisis yang digunakan untuk memahami kondisi perilakuperilaku dari sebagian kelompok-kelompok kecil dalam suatu wilayah tertentu. Dalam pembahasan kali ini akan dikaji bagaimana sifat-sifat bangunan dan prasarana lain yang terbangun dengan orientasinya terhadap jalanjalan penghubung dalam permukiman.

1. Jalan Lurus

Pada Gambar 3 dapat dilihat jalan tidak berkelok cenderung memberi sifat kepada masyarakat setempat untuk membangun permukiman menyusuri jalan tersebut.

\section{Jalan Berkelok}

Pada Gambar 4 dapat dilihat perkelokan cenderung dimanfaatkan sebagai ruang lebur untuk digunakan bersama dengan memberinya keleluasaan fungsi menjadi ruang terbuka untuk publik.

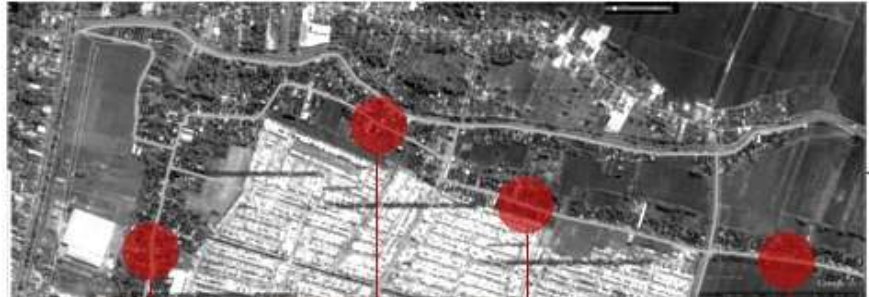

Gambar 3. Pola Pemetaan Jalan Lurus (sumber: images.google.com)

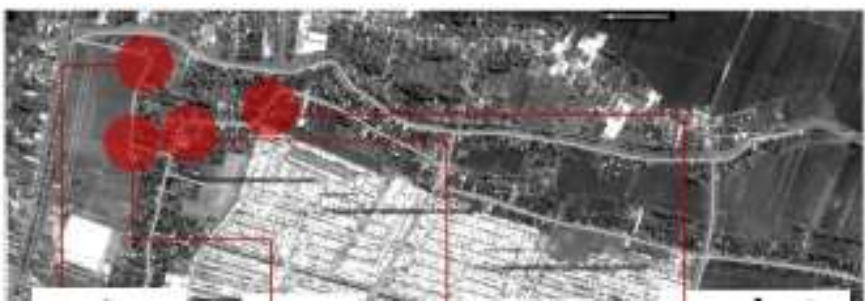

Gambar 4. Pola Pemetaan Jalan Berkelok

(sumber: images.google.com)

\section{Jalan Persimpangan}

Persimpangan bisa dikatakan sendi yang menghubungkan berbagai jalan kota. Pada persimpangan dalam perancangan permukiman tidak hanya sebagai ruang terbuka untuk masyarakat, tapi juga akan dikonsentrasikan sebagai titik perekonomian. Dimanfaatkan sebagai area bisnis dan perdagangan. Perencanaan wilayah untuk area bisnis dan perekonomian akan ditempatkan pada bagian strategis dari perancangan permukiman.

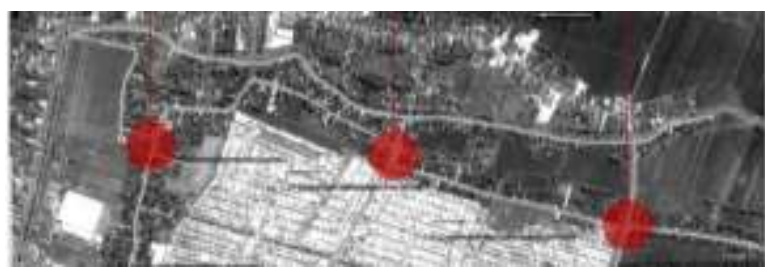

Gambar 5. Pola Pemetaan Jalan Persimpangan

Pada Gambar 5 di atas persimpangan bisa dikatakan pusat pertemuan yang menghubungkan berbagai jalan kota.

\subsection{Analisis Makro}

Analisis kawasan makro merupakan analisis yang dirancang pertama karena dalam perancangan ini, tahapan paling awal adalah menentukan lokasi yang kemudian digunakan untuk melakukan duplikasi dan pengembangan. Pola yang kali ini akan diteliti adalah bagaimana kecenderungan masyarakat 
tinggal jika dikaitkan dengan fasilitas-fasilitas umum dan sarana dan prasarana kota.

1. Sarana Transportasi

Kepadatan lebih banyak terjadi di dekat jalan besar yang menghubungkan Surabaya-Porong-Sidoarjo. Jalur transportasi merupakan tulang untuk daging-daging permukiman yang akan tumbuh dan berkembang, jalur transportasi juga menjadi roda utama penggerak putaran ekonomi wilayah sekitarnya.

2. Sarana Penunjang Ekonomi

Dalam sejarahnya wilayah terdampak termasuk kedalam wilayah strategis perekonomian karena terdapat beberapa pabrik dan pasar yang kini telah tertutup lumpur Lapindo. Pusat perekonomian seperti pasar juga lah yang kemudian dengan sendirinya membentuk pola aktivitas masyarakat di sekitarnya, ada kecenderungan penempatan lokasi permukiman dari keberadaan pasar di sana.

3. Prasarana Penunjang Transportasi

Prasarana penunjang transportasi seperti terminal dan stasiun pun menjadi poros dalam tumbuh dan berkembangan permukiman pada khususnya dan kota pada umumnya.

\subsection{Analisis Bentuk dan Tampilan Bangunan}

Pola jaringan memiliki variasi kelebihan serta kekurangannya masing-masing, konsep jaringan yang akan digunakan merupakan konsep jaringan yang paling efektif serta fleksibel terhadap tapak yang organis dan rangkaian tanggul yang masih dimungkinkan untuk berubah. Pola jaringan dipelajari dari tiga bentuk dasar, yaitu segitiga, persegi, dan lingkaran.

Bentuk segitiga merupakan bentuk dengan ikatan jejaring paling kuat dengan kemungkinan setiap pertemuannya dapat disesuaikan dengan kondisi tapak, efektifitas ruang yang kurang kemudian coba dikembangkan kembali dengan mengadopsi dan menggabungkan segitiga-segitiga ini hingga tercapai konsep jejaring yang ideal, seperti dapat dilihat pada Gambar 6 berikut ini.

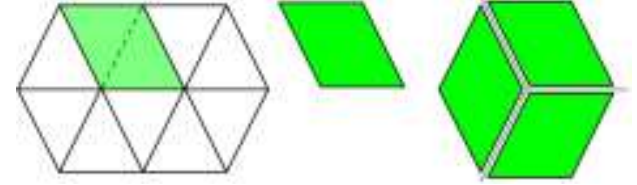

Gambar 6. Pengembangan Bentuk Jaringan

Jejaring pada Gambar 4 dapat menjawab permasalahan lingkungan permukiman berkonsep sel yang tertutup dengan tersedianya jalur-jalur sirkulasi tambahan saat berjejaring, juga dengan bentuk yang tidak sekaku persegi, bentuk ini memiliki fleksibilitas yang tinggi untuk menyesuaikan diri terhadap kondisi tapak.

\subsection{Analisa Struktur}

Berada langsung di atas lumpur yang tidak memiliki kekuatan daya dukung tanah, permukiman tumbuh akan dibangun di atas struktur yang sesuai untuk kondisi tersebut yaitu menggunakan struktur aquapolis (Kikutake, 1997) seperti pada Gambar 7 berikut.

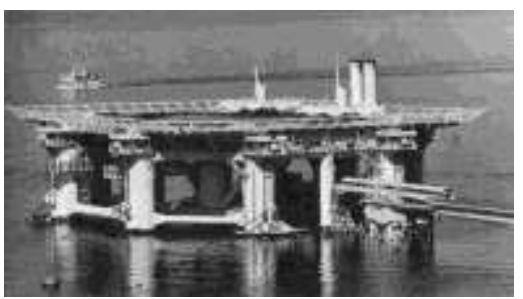

Gambar 7. Struktur Aquapolis (sumber: evhuang, geocities.ws)

Struktur ini akan menjadi basis Permukiman Tumbuh di atas Lahan Bencana Lumpur Lapindo. Struktur dasar ini akan diperpanjang dengan tiang pancang hingga strukturnya mencapai ke tanah keras.

Permukiman yang akan dibangun di atas struktur dasar tentunya juga harus memiliki persiapan untuk menghadapi bencana yang kemungkinan akan terjadi, dalam konsep ini akan diaplikasikan struktur untuk mempertahankan bangunan dari bencana gempa sebagai bencana yang paling sering dan tidak dapat diprediksi di Indonesia.

1. Struktur Belt Truss

Struktur Belt Truss (lihat Gambar 8) merupakan struktur pengikat jaringan balok-balok yang terdapat pada satu tingkatan ketinggian, kemudian dikaitkan kepada struktur utama bangunan. Struktur ini merupakan struktur efisien untuk 
bangunan bertingkat karena tidak perlu diaplikasikan pada setiap tingkatan ketinggian, cukup pada beberapa tingkatan.
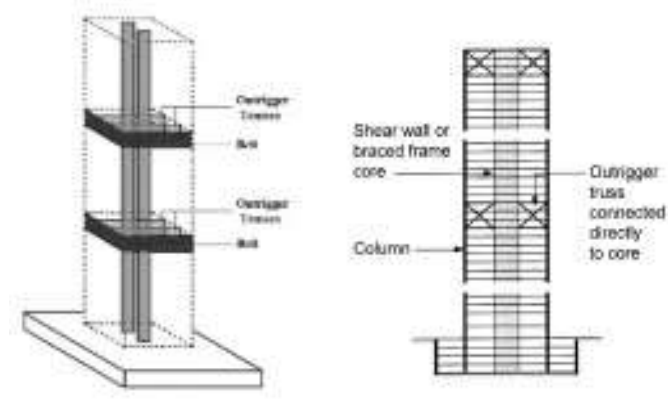

Gambar 8. Struktur Belt Truss (sumber: www.civildigital.com)

\section{Permukiman Modular}

Modular berarti dapat diganti, permukiman tumbuh didesain dengan prinsip metabolisme yang beradaptasi sebagaimana kondisinya (lihat Gambar 9). Hunian permukiman merupakan desain modular yang dapat dilepas pasang sesuai kebutuhan.

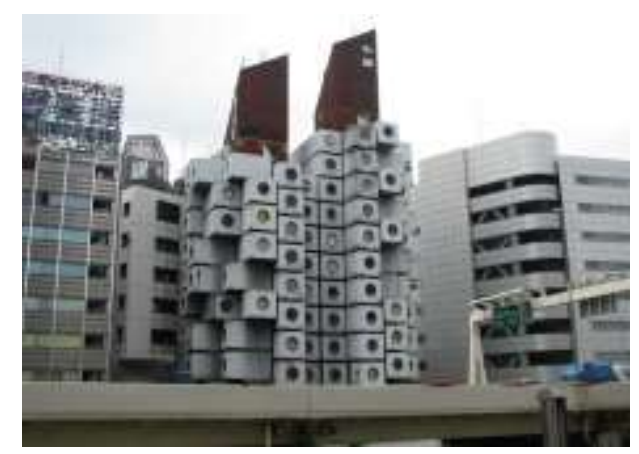

Gambar 9. Nakagin Capsule Tower (sumber: evhuang, geocities.ws)

Konsep struktur masif ini diadaptasi dari konsep arsitek Kikutake yang telah diaplikasikannya pada karyanya "Sky House". (Koolhaas, 2011)

\subsection{Konsep Sirkulasi}

Sirkulasi merupakan bagian vital pada desain permukiman tumbuh, karena merupakan penghubung yang akan saling mengaitkan antara satu jaringan dengan jaringan baru lain yang akan tumbuh. Konsep sirkulasi merupakan perpaduan antara lingkungan berkonsep sel dengan lingkungan berkonsep linear (lihat Gambar 10).
Kelemahan sistem sel adalah ruang bergerak yang terbatas karena sirkulasi yang sangat minim yang terdapat di lingkungannya. Kekurangan ini kemudian dikombinasikan dengan pola permukiman linear yang secara garis besar merupakan permukiman dengan orientasi utama terhadap jalan (jalur sirkulasi).

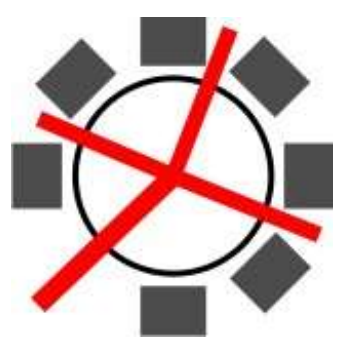

Gambar 10. Konsep Permukiman Semi cul de sac

Konsep semi cul de sac ini mampu menjawab kekurangan dari sistem tertutup, juga memberikan solusi untuk sebuah jaringan permukiman dapat terkoneksi dengan jaringan yang lain melalui sirkulasi-sirkulasi yang telah direncanakan.

\section{KESIMPULAN (KONSEP DESAIN)}

Konsep rancangan permukiman tumbuh merupakan sebuah adaptasi langsung terhadap tapak yang pada desain kali ini menyelesaikan permasalahan pada lumpur Lapindo. Hal itu dapat membuka gagasan tentang pemanfaatan lahan terdampak yang selama ini menjadi masalah karena tidak adanya kemungkinan untuk dimanfaatkan. Gambar 11 merupakan gambar desain akhir dari gagasan Permukiman Tumbuh di Atas Lumpur Lapindo ini.

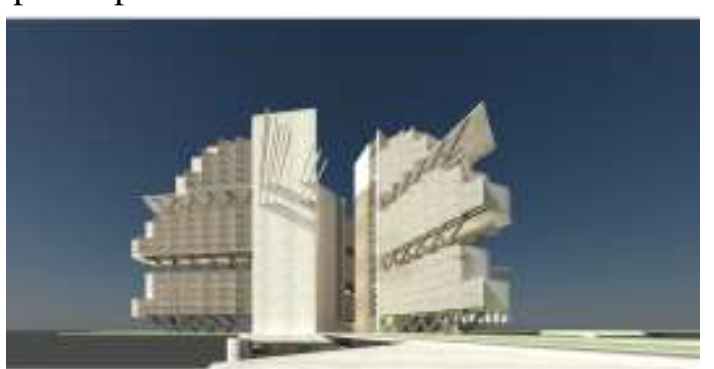

Gambar 11. Perspektif Permukiman

Jejaring permukiman merupakan gagasan utama dari pendekatan Metabolisme, terlihat seperti Gambar 12 di bawah ini. 


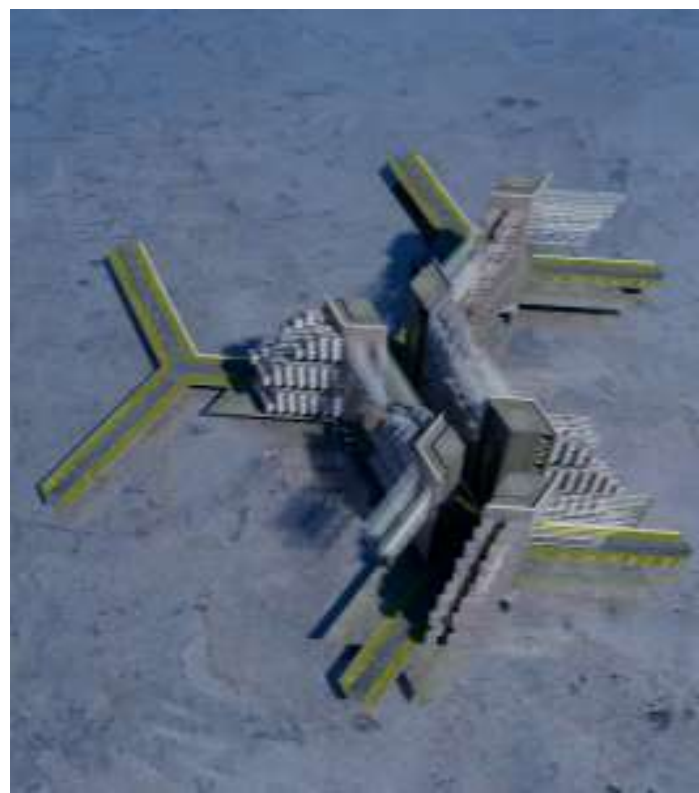

Gambar 12. Jaringan Permukiman Tumbuh

\section{REFERENSI}

Civil Digital (2016). The efficient use of outrigger and belt truss in tall buildings. http://civildigital.com/efficient-useoutrigger-belt-truss-tall-buildings/. Diakses Juni 2016.

Evhuang. Geocities.[online]. Tersedia: http://www.geocities.ws/evhuang/japana rch/aquapolis.JPG [28 Juli 2016]

Evhuang. Geocities.[online]. Tersedia: http://www.geocities.ws/evhuang/japana $\mathrm{rch} /$ trans5.html [28 Juli 2016]

Kikutake K (1997). From tradition to utopia. Arcadeozini: Milan.

Koolhaas Rem (2011). Metabolism Talk.

Syafi. Tempo.[online]. Tersedia: http://www.tempo.co/read/news/2014/03 /27/063565862/negara-bisa-paksalapindo-bayar-rp-1-5-triliun [28 Juli 2016] 